\title{
Pemberdayaan Pokdarwis Desa Sidowayah Berbasis Penguatan Branding Di Era Revolusi Industri 4.0
}

\author{
Muhammad Rustamaji ${ }^{1}$, Bambang Santoso ${ }^{2}$, Kristiyadi $^{3}$, \\ Sri Wahyuningsih Yulianti ${ }^{4}$, Edy Herdyanto ${ }^{5}$ \\ 1,2,3,4,5 Fakultas Hukum, Universitas Sebelas Maret (UNS), Surakarta, Indonesia \\ ${ }^{1}$ muhammad_rustamaji@staff.uns.ac.id
}

\begin{abstract}
Abstrak
Desa Sidowayah, Polanharjo, Klaten yang terkenal dengan destinasi wisata Umbul Manten dan Umbul Siblarak, ternyata belum mempunyai buah tangan yang mengesankan bagi para wisman. Meskipun terdapat produk olahan yang bersumber dari sektor perikanan, dan pertanian, namun masih dikemas secara sangat bersahaja dan dipasarkan secara konvensional. Kondisi demikian sangat disayangkan karena tidak sejalan dengan perkembangan Revolusi Industri 4.0 yang melaju dengan pesat. Atas kondisi demikian, produk lokal yang masih dikemas secara bersahaja dengan pemasaran konvensional tersebut, sejatinya berpotensi untuk ditingkatkan menjadi buah tangan khas layaknya produk unggulan dari suatu destinasi wisata. Oleh karenanya, Kelompok Sadar Wisata (Pokdarwis) maupun Tim Penggerak Pemberdayaan Kesejahteraan Keluarga (TP-PKK) dipilih sebagai mitra kerjasama Pengabdian Masyarakat guna penguatan branding produk lokal Sidowayah, sekaligus guna memproteksi HKI dalam mengkomodifikasi produk olahan Sidowayah. Pengabdian dilaksanakan dengan metode Participatory Rural Appraisal (PRA). Langkah utama pelaksanaan pengabdian dibagi dalam empat tahap. Tahap pertama menggunakan metode instruksional dan komunikasi dua arah melalui kegiatan sosialisasi urgensi penguatan branding produk lokal yang sudah dikembangkan dalam komoditas nugget, bakso dan fish skin. Tahap kedua praktik pengemasan produk dan penguatan konten branding dan pendaftaran merek dagang berbasis perlindungan Hak Kekayaan Intelektual (HKI). Tahap ketiga, pemasaran digital yang memanfaatkan sosial media serta publikasi lini massa dan online. Tahap keempat, monev atas kegiatan penguatan branding dan proteksi HKI produk Sidowayah. Meski belum optimal, program pengabdian telah meletakkan fondasi untuk terciptanya penguatan branding produk unggulan desa yang dikomodifikasi, meningkatkan income generating, dan terwujudnya masyarakat yang berdikari dalam ekonomi berbasis produk lokal.
\end{abstract}

Kata Kunci: branding produk, kekayaan intelektual, Sidowayah.

\section{PENDAHULUAN}

Menelaah perjalanan otonomi daerah di era kekinian, dapat dirasakan bahwa bentuk paling riil mengenai implementasi otonomi dalam hal keuangan tentu saja diwujudkan dalam format pengucuran dana desa (Widjaja, 2008, p.165). Melalui dana desa inilah, jumlah keseluruhan desa yang saat ini mencapai 74.000 (tujuh puluh empat ribu) terbuka kesempatannya untuk menghasilkan produk unggulan desa yang menjadi sumber Pendapatan Asli Desa (PADes).

Pada konteks Desa Sidowayah Polanharjo, pengucuran dana dari pemerintah pusat hingga ke pemerintah desa yang sudah dilaksanakan sejak Ekonomi, Sosial, dan Budaya

1123 
2015 dapat dikatakan ternyata telah dimanfaatkan untuk menghasilkan beragam produk makanan olahan berbahan kekayaan alam lokal. Namun demikian, beragam produk olahan yang bersumber dari sektor perikanan, pertanian dan pembudidayaan tersebut ternyata masih dikemas secara sangat bersahaja dalam kemasan plastik. Kondisi demikian tentu sangat disayangkan karena tidak sejalan dengan perkembangan Revolusi Industri 4.0 yang saat ini melaju dengan sangat pesat. Kondisi yang sangat disayangkan demikian juga dikarenakan meskipun Desa Sidowayah terkenal dengan destinasi wisata berwujud Umbul Manten dan Umbul Siblarak, akan tetapi ternyata belum mempunyai buah tangan yang mengesankan bagi para wisman. Atas kondisi demikian, keberadaan makanan olahan berbahan lokal yang masih dikemas secara bersahaja dan dijual secara konvensional tersebut, sejatinya justru berpotensi untuk ditingkatkan menjadi buah tangan khas layaknya produk unggulan dan oleh-oleh dari suatu destinasi wisata.

Ilustrasi terkini Desa Sidowayah tersebut menggambarkan bagaimana ekonomi kerakyatan meskipun masih ditempatkan sebagai pendulum utama pencapaian kemakmuran, namun demikian kelestarian ekologi yang ada tetap dijaga (Hasmawati, 2018). Akan tetapi problematik kesahajaan pola pengemasan, pemasaran destinasi desa, hingga proteksi hak kekayaan intelektual (HKI) cita rasa boga pedesaan masih belum menemukan solusi yang sesuai (match) karena terlalu mengedepankan metode tradisional untuk tidak dikatakan sudah obsolete ketika diperbandingkan dengan kecepatan inovasi di era revolusi industri 4.0.

Pada kulminasi inilah sebuah pemikiran dari Yuswohady (2015) mengenai lima sila untuk memenangi persaingan di era industrialisasi global utamanya di kancah reifikasi global dunia, patut direnungkan bersama. Langkah-langkah kreatif dan berdaya juang lebih ditekankan bagi setiap anak bangsa yang ingin menjadi pelaku usaha, daripada mengedepankan solusi eksploitasi ekologi demi perluasan jangkauan ekonomi. Dapat dicermati Sila 1, use local advantages to kick the competitions, pelaku usaha harus cerdas memanfaatkan keunikan lokal untuk memenangkan persaingan. Karakteristik pelaku usaha demikian disebut tipe local champion.
Sila 2, create local innovation to make competition irrelevant, pelaku usaha harus memanfaatkan inovasi dan menciptakan pasar baru yang minim persaingan. Karakteristik pelaku usaha seperti ini disebut creative master. Sila 3 , boost excellence to beat the giant, pelaku usaha tipe ini menempuh langkah habis-habisan untuk mendongkrak kualitas produk atau jasanya guna mengalahkan pesaing. Karakteristik pelaku usaha demikian disebut quality challenger. Sila 4, build bigness through mass partnership, pelaku usaha tipe ini merupakan pemain kecil yang bermain di pasar ceruk (niche), akan tetapi jika pemain kecil ini dihimpun menjadi satu kesatuan maka mereka akan memiliki kekuatan yang luar biasa. Karakteristik pelaku usaha demikian disebut longtail collaborator. Sila 5, achieve global best practices to win foreign market, pelaku usaha tipe ini merupakan pelaku usaha yang fokus dan berkonsentrasi tinggi untuk benar-benar bersaing di pasar internasional. Karakter pelaku usaha demikian sangat istimewa karena mereka menyasar keunggulan di segala aspek sebelum memasuki pasar internasional, baik dari segi permodalan, teknologi, manajemen, sumber daya manusia (SDM) yang kesemuanya berstandar dunia. Karakter pelaku usaha ini disebut global chaser yang sejak semula menempatkan diri sebagai pelaku usaha pada jajaran terbaik dunia (global best practice) (Yuswohady, 2015).

Berdasarkan gambaran teoretik demikian, guna mencapai kualifikasi quality challenger atau setidaknya menjadi longtail collaborator bagi pemangku kepentingan Desa Sidowayah, tidak ada kata lain harus dilakukan pemberdayaan dan kolaborasi. Oleh karenanya, Kelompok Sadar Wisata (Pokdarwis) maupun Tim Penggerak Pemberdayaan Kesejahteraan Keluarga (TP-PKK) dipilih sebagai mitra untuk bekerjasama dengan Tim Pengabdian Masyarakat ini guna melaksanakan serangkaian pemberdayaan masyarakat dengan cara penguatan branding produk lokal Desa Sidowayah, sekaligus guna memproteksi kekayaan inelektual masayarakat Desa Sidowayah dalam mengkomodifikasi produk olahan yang bercitarasa khas pedesaan.

\section{METODE}

Metode yang digunakan dalam kegiatan pengabdian ini adalah Participatory Rural Ekonomi, Sosial dan Budaya 1124 
Appraisal (PRA). Robert Chambers (1994) mengemukakan Participatory Rural Appraisal merupakan suatu metode pendekatan dalam proses pemberdayaan dan peningkatan partisipasi masyarakat, yang tekanannya pada keterlibatan masyarakat dalam keseluruhan kegiatan pembangunan, terutama menyangkut konsep mengenai pembelajaran yang fleksibel di lapangan, nilai penting dari observasi-partisipasi, pentingnya pendekatan (rapport), pembedaan cara pandang etik (cara pandang pengabdi) dan emik (cara pandang anggota komunitas), serta validitas dari pengetahuan lokal (Chambers, 1996:955). Pendekatan PRA dimaksudkan menjadikan warga masyarakat sebagai perencana, pelaksana program pembangunan dan bukan sekedar objek pembangunan (Britha,2011).

Kegiatan utama pengabdian ini dibagi dalam empat tahap. Tahap pertama menggunakan metode instruksional, survey (Morissan,2012) dan dialog melalui kegiatan sosialisasi optimalisasi peran branding produk lokal dan proteksi hak kekayaan intelektual (HKI). Tahap ini memfokuskan diri pada perubahan mindset komodifikasi produk lokal melalui perbaikan kemasan produk serta manajemen pemasarannya. Tahap kedua dilakukan praktik pembuatan kemasan kreatif ramah lingkungan dan beragam metode pemasaran berproteksi HKI. Tahap ketiga adalah pemasaran digital yang memanfaatkan sosial media serta publikasi media massa dan online serta pendaftaran merek. Tahap keempat yaitu pendampingan untuk memonitor dan mengevaluasi kendala selama program berlangsung.

\section{HASIL DAN PEMBAHASAN}

\section{Profil Mitra}

Desa Sidowayah-Polanharjo, Klaten merupakan salah satu desa yang dikaruniai sumber mata air yang bersumber dari lereng Gunung Merapi. Potensi air yang melimpah dan mengalir sepanjang tahun demikian, secara bijaksana telah dimanfaatkan oleh warga untuk membudidayakan peikanan air tawar, utamanya nila (Ningrum et.al, 2019). Pemanfaatan air juga dioptimasi di sektor persawahan, hingga di sektor pariwisata air dengan memanfaatkan sumber mata air yang dialirkan ke dalam embung atau umbul desa.

Atas hasil budidaya perikanan, telah dihasilkan banyak komoditas lokal berwujud makanan ringan berbahan dasar kulit ikan nila (nila's fish skin), hingga kudapan aneka sayur yang dikelola oleh ibu-ibu Tim Penggerak PKK Desa Sidowayah. Beragam komoditas lokal dengan citarasa pedesaan demikian sangat digemari oleh para pengunjung yang rata-rata datang dalam jumlah besar (rombongan). Potensi demikian semakin dilipatgandakan setelah dibangunnya umbul/embung di desa Sidowayah, pada blok persawahan Siblarak.

Pemandangan persawahan yang dipadu dengan jernihnya umbul Siblarak menjadi 'magnet' tersendiri bagi pengunjung untuk berlama-lama di Desa Sidowayah. Terbentuknya kelompok sadar wisata (Pokdawis) yang digawangi oleh para pemuda Desa Sidowayah, menjadi unsur penguat perintisan Desa Sidowayah menjadi destinasi wisata yang diminati wisatawan.

Mencermati profil desa demikian, maka Kelompok Sadar Wisata (Pokdarwis) maupun Tim Penggerak Pemberdayaan Kesejahteraan Keluarga (TP-PKK) ditempatkan sebagai mitra untuk bekerjasama dengan Tim Pengabdian Masyarakat ini guna melaksanakan serangkaian pemberdayaan masyarakat dengan cara penguatan branding produk lokal Desa Sidowayah, sekaligus guna memproteksi kekayaan intelektual masyarakat Desa Sidowayah dalam mengkomodifikasi produk olahan yang bercitarasa khas pedesaan.

\section{Analisis Permasalahan Mitra}

Berdasarkan uraian sebelumnya, meskipun warga Desa Sidowayah sudah menghasilkan komoditas lokal, akan tetapi pengemasan dan pola pemasaran di era Revolusi Industri 4.0 agaknya masih perlu ditingkatkan. Hal ini dapat dilihat dari pengemasan beragam produk komoditas lokal dalam bungkus plastik. Sementara di saat yang sama, Pokdarwis Desa Sidowayah maupun Tim Penggerak PKK masih memfokuskan pemasaran melalui layanan langsung bagi pengunjung yang datang ke destinasi Umbul Siblarak.

Menelaah kedua kondisi tersebut, baik pada sisi pengemasan maupun pemasaran produk lokal Desa Sidowayah, tentu diperlukan pemberdayaan bagi mitra. Oleh karenanya permasalahan

$$
\text { Ekonomi, Sosial, dan Budaya }
$$

1125 
pengemasan akan diupayakan penyelesaiannya dengan pemberdayaan di sektor pengemasan dan desain pembungkus produk berbasis merek dagang. Adapun pemasaran tradisional diproyeksikan diberdayakan dengan pola pemasaran digital berbasis medsos dan video teaser yang berkesesuaian dengan Revolusi Industri 4.0.

\section{Tahapan Kerja Kegiatan Pengabdian}

Pemberdayaan masyarakat Desa Sidowayah c.q. Pokdarwis BUMDes Sinergi dilaksanakan dengan kombinasi antara kegiatan lapangan/luring (offline) dan daring (online). Metode kombinasi demikian dikarenakan tingkat pandemi yang ada di lokasi kegiatan meskipun masuk zona hijau, namun tidak demikian dengan wilayah di sekitar Sidowayah. Selanjutnya metode pelaksanaan kegiatan Pengabdian Kepada Masyarakat ini adalah Participatory Rural Appraisal (PRA).

Berdasarkan hasil analisis permasalahan mitra, tim pengabdi selanjutnya mendorong terwujudnya forum pelatihan dan workshop untuk menumbuhkan kesadaran bersama akan pentingnya branding produk lokal dan modernitas pemasaran di era Revolusi Industri 4.0 di Desa Sidowayah. Tim pengabdian masyarakat menyiapkan materi tentang isi dan arah pelaksanaan PRA sebagai salah satu perwujudan metode partisipatoris. Secara garis besar, keseluruhan tahapan kerja yang dilaksanakan pada program pengabdian meliputi sosialisasi program ke mitra, sosialisasi pengolahan produk perikanan untuk mendukung pariwisata Sidowayah, praktik pembuatan produk lokal (nugget ikan, bakso ikan, fish skin), praktik pengemasan produk lokal, sosialisasi manajemen pemasaran dan pembukuan keuangan serta virtual tourism, promosi produk, pendaftaran merek, pendampingan, monitoring dan evaluasi, diseminasi hasil kegiatan dan publikasi, serta pelaporan. Melalui pendekatan PRA, mitra diajak menyelami urgensi pembangunan sosial yang visinya yaitu terwujudnya kemandirian masyarakat dengan sejumlah prinsip yang melandasainya, misalnya mendorong program pembangunan dilaksanakan secara swadaya dan penuh kebersamaan.

Oleh karena pelaksanaan program lebih menekankan praktik daripada penguasaan pengetahuan mendalam, pelatihan dipandu oleh para narasumber dan khususnya fasilitator untuk mempraktikkan PRA. Narasumber dari kalangan tim pengabdi juga bukan orang yang banyak menceritakan tentang dirinya dan pengalamannya, melainkan membantu mitra untuk memetakan kembali pengalamannya dari beberapa pengetahuan dan pengalaman narasumber yang dihadirkan dalam mempromosikan produk lokal yang telah mengalami perbaikan pengemasan.

Pada tahap awal, sosialisasi program ke mitra dimaksudkan untuk menyampaikan tujuan program dan kegiatan. Sosialisasi optimalisasi pengolahan produk perikanan untuk mendukung pariwisata Sidowayah disampaikan oleh Muhammad Rustamaji dan Bambang Santoso sedangkan sosialisasi manajemen pemasaran dan pembukuan keuangan akan disampaikan oleh SW. Yuliyanti. Adapun pelatihan pembuatan olahan ikan dan pengemasan disampaikan Rysca Indreswari sebagai narasumber yang dihadirkan dalam sosialisasi karena pengalamannya sebagai content creator dan food vloger Dapur Emak (Indreswari, 2019).

Pada pertemuan ketiga, kelompok pelatihan yang sudah terbentuk dipisah menjadi tim kecil yang memfokuskan diri pada bidang yang berbeda. Tim A yang mayoritas beranggotakan ibuibu PKK dan remaja putri Pokdarwis BUMDes Sinergi memfokuskan diri pada praktik pembuatan produk lokal (nugget ikan, bakso ikan, fish skin) yang dibersamai oleh tim pengabdi dan narasumber yang dihadirkan. Tim B yang mayoritas beranggotakan bapak-bapak Pokdarwis BUMDes Sinergi dan beberapa pemuda Karang Taruna Sidowayah memfokuskan diri membuat spot foto yang instragramable. Adapun Tim C yang beranggotakan remaja karang taruna dan pokdarwis menfokuskan diri belajar memotret, mengedit 
video, dan pembuatan katalog virtual berbasis WA Bisnis.

Adapun roadmap kegiatan utama pengabdian ini dibagi dalam empat tahap. Tahap pertama menggunakan metode instruksional dan dialog melalui kegiatan sosialisasi virtual tourism maupun strategi peningkatan produk lokal (dari diversifikasi, pengemasan, hingga pemasaran) untuk mendukung pariwisata Sidowayah. Tahap kedua dilakukan praktik pembuatan platform virtual tourism (media sosial-360 ${ }^{\circ}$, panoramic images, start-up SINERGI, You Tube Channel SINERGI) dan diversifikasi produk lokal (nugget ikan, bakso ikan, fish skin), pengemasan, hingga pemasaran (konvensional dan via e-food truck). Tahap ketiga adalah pemasaran digital yang memanfaatkan sosial media serta publikasi media massa dan online serta pendaftaran merek produk olahan ikan. Tahap keempat yaitu pendampingan untuk memonitor dan mengevaluasi kendala selama program pengabdian berlangsung.

Secara lebih detail, penguraian kegiatan pengabdian berdasarkan roadmap dapat dijelaskaan melalui tahapan-tahapan dalam pelaksanaan kegiatan sebagai berikut: (1).Survei Lokasi. Survei lokasi dilakukan dengan mengamati kondisi dan potensi desa. Tim Pengabdian Kepada Masyarakat mengadakan pertemuan dengan kepala desa dan Direktur BUMDes Sinergi untuk menjelaskan tujuan dari Tim Pengabdian Kepada Masyarakat, kemudian mengumpulkan data monografi, topografi dan potensi Desa Sidowayah. (2).Identifikasi Masalah. Identifikasi masalah dilakukan melalui wawancara dengan kepala desa dan Direktur BUMDes Sinergi mengenai potensi dan permasalahan desa serta kelembagaan Pokdarwis. (3).Analisis Kebutuhan. Tim bersama kepala desa dan mengidentifikasi serta merumuskan solusi permasalahan yang akan dikelola melalui Tim Pengabdian Kepada Masyarakat. (4).Penetapan Khalayak Sasaran. Khalayak sasaran dalam program ini adalah anggota Pokdarwis BUMDes Sinergi yang menjadi pengelola agropolitan Sidowayah di bidang pertanian, perikanan dan wisata yang masih memerlukan pembinaan, pelatihan dan penyuluhan dengan pemanfaatan virtual tourism guna meningkatkan perekonomian desa (Sabil. 2014). (5).Penyusunan Program. Penyusunan program dilakukan oleh tim Pengabdian Kepada Masyarakat bersama mitra. Program yang dikerjakan meliputi: sosialisasi konsep virtual tourism maupun strategi peningkatan produk lokal. Pelatihan pembuatan aplikasi (platform) virtual tourism (media sosial-360 ${ }^{\circ}$, panoramic images, start-up SINERGI, You Tube Channel SINERGI) dan diversifikasi produk lokal (nugget ikan, bakso ikan, fish skin) (Suyanto, 2010), pengemasan hingga pemasaran (offline/konvensional dan via e-food truck) maskot, pelatihan manajemen pemasaran digital era new normal menggunakan aplikasi Virtual Tourism SINERGI, penguatan Instagram @wisata_siblarak dan Facebook pesona_siblarak, pendaftaran merek dagang "Sinergi" dan hak cipta, promosi produk dan publikasi di televisi, media cetak dan online, diseminasi hasil program dan publikasi di jurnal, lokakarya hasil dengan menghadirkan stakeholder dan pelaporan. (6).Perumusan dan Pengukuran Indikator Keberhasilan. Perumusan dan pengukuran indikator keberhasilan program diuraikan dengan tiga parameter sebagai berikut: a).Perubahan perilaku masyarakat dan meningkatnya pengetahuan serta keterampilan dalam pengembangan potensi agropolitan (Direktorat Jenderal Cipta Karya, 2012), terutama melalui virtual tourism. Pengukuran indikator dilakukan dengan pretest dan posttest pada saat sebelum dan sesudah sosialisasi dengan tema "Pemanfaatan Platform Virtual Tourism Agropolitan di Era New Normal". Peningkatan pengetahuan dan sikap diukur dengan membandingkan nilai pretest dan posttest dengan uji Wilcoxon. Pertanyaan terdiri dari 15 soal untuk tes pengetahuan dan 10 soal tes sikap. Aspek pengetahuan yang diukur meliputi pengetahuan tentang virtual tourism dan diversifikasi produk lokal dengan pemanfaatan teknologi untuk mendukungnya. Pertanyaan mengenai sikap diuraikan untuk mengetahui pola pikir dan tingkat partisipasi masyarakat dalam mengadopsi program. 
Hasil pretest dan posttest dianalisis secara deskriptif dalam bentuk tabulasi. Perbedaan nilai pretest dan posttest merupakan perubahan tingkat pengetahuan dan sikap. Untuk mengetahui peningkatan pengetahuan dan sikap digunakan kriteria persentase efektivitas dengan rumus $=((\mathrm{PS}-$ $\mathrm{PR}) /(\mathrm{N} 2 \mathrm{Q}-\mathrm{PR})) \times 100 \%$, dengan $\quad \mathrm{PS}=$ posttest, $\mathrm{PR}=$ pretest, $\mathrm{N}=$ jumlah responden, $2=$ nilai tertinggi, $\mathrm{Q}=$ jumlah pertanyaan, $100 \%=$ pengetahuan yang ingin dicapai. PS-PR merupakan peningkatan pengetahuan dan N2Q-PR merupakan nilai kesenjangan. Persentase efektivitas tingkat pengetahuan dibagi atas tiga kriteria (Ginting, 1991) yaitu: kurang efektif $(<32 \%)$, cukup efektif $(\geq 32-$ $64 \%$ ) dan efektif ( $\geq 64 \%$ ). b).Terjalin kemitraan dengan berbagai pihak seperti Dinas Pariwisata, Pemuda dan Olah Raga Kabupaten Klaten dan GenPI Jateng yang dapat mendukung kesuksesan dan keberlanjutan program. c).Penguatan kelembagaan lokal BUMDES Sinergi yang dapat meneruskan keberlanjutan pengembangan program. Kelembagaan tersebut bertanggungjawab untuk keberlangsungan pengelolaan program. (7).Pelaksanaan Program.

Pelaksanaan program diawali dengan sosialisasi ke mitra dilanjutkan dengan pelatihan yang meliputi pembuatan platform virtual tourism dan produk lokal. Pelatihan mengundang narasumber Rysca Indreswari, S.Pt., M.Si selaku pakar agribisnis dan kuliner. Produk lokal unggul berupa fish skin, bakso ikan, nugget ikan diproyeksikan sebagai ciri khas kuliner Sidowayah. Fish skin kemasan disajikan dengan varian: volcano, mercon, rasa bawang, dan original. Adapun minuman, BUMDes sudah memiliki air mineral dalam kemasan siap saji. Untuk memberikan dampak positif bagi mitra dan memaksimalkan added value pada produk maka perlu ditambahkan kemasan yang menarik. Pendaftaran merek dagang di Direktorat Jenderal Kementrian Hukum dan HAM dilakukan untuk melindungi produk dan memberikan pembeda dengan produk sejenis dari kompetitor. Pemasaran dilakukan secara offline dengan pembuatan portable food truck, sedangkan pemasaran secara online dirintis dengan sistem startup menggunakan aplikasi e-food truck SINERGI. Food truck akan beroperasi setiap hari, di Umbul Siblarak pada Sabtu dan Minggu serta berkeliling di Klaten dan sekitarnya pada Senin hingga Kamis. Selain menjual produk BUMDes, food truck juga mempunyai misi mempromosikan pariwisata Umbul Siblarak. Selain menyediakan produk kemasan, food truck juga berfungsi sebagai mini portable resto yang menyediakan menu nasi dengan aneka produk lokal Sidowayah dan minuman mineral siap saji.

Pengoperasian aplikasi Virtual Tourism melibatkan akun penjual dan pembeli, akun pembeli berisi informasi mengenai food truck, harga dan menu yang masih tersedia serta informasi pariwisata Umbul Siblarak. Akun penjual mengaktifkan sinyal yang akan ditangkap oleh pembeli sebagai lokasi food truck dan menerima pesanan dari akun pembeli. Launching program diadakan di kawasan wisata Umbul Siblarak dengan menghadirkan kepala Dinas Pariwisata, Pemuda dan Olah Raga, food vlogger dan selebgram. Peran food vlogger dan selebgram dalam launching adalah sebagai influencer untuk mempromosikan Siblarak di era new normal dan produk BUMDes Sinergi. Promosi melalui instagram dengan menandai akun official Sinergi serta kuliner Sidowayah serta hastag yang berfungsi untuk memperluas jangkauan informasi. Ikon wisata "Siblarak" dipasang di kawasan umbul sebagai identitas dan branding strategy untuk menarik minat wisatawan. Selain ikon "Siblarak" upaya branding strategy lainnya adalah dengan maskot. Pembuatan maskot merupakan upaya promosi yang bisa memberikan impresi yang baik bagi pengunjung dan penting bagi pengembangan pariwisata Siblarak. (8).Strategi Pembinaan Khayalak Sasaran. Program ini tidak hanya memberikan pelatihan dan aset untuk mendukung pemberdayaan, tetapi yang utama adalah mengubah mindset masyarakat sasaran dari stagnasi akibat pandemi menjadi lebih kreatif dan inovatif terhadap potensi desa dengan menerapkan teknologi digital.

$$
\text { Ekonomi, Sosial dan Budaya }
$$


Pembinaan dilakukan dengan menambahkan added value pada produk lokal yang dihasilkan, seperti fish skin, bakso ikan, dan nugget ikan. Pelatihan ditujukan untuk memperbaiki cara pengemasan yang sederhana dan pemasaran yang konvensional menjadi terintegrasi melalui penggunaan aplikasi. (9).Perintisan Kemitraan. Perintisan program kemitraan didasari dengan tujuan yang sama antara tim dan mitra sehingga terbentuk lembaga yang lebih kuat. Tim merintis mitra melalui kemitraan yang sesuai dengan kesamaan tujuan sehingga terbentuk penguatan BUMDes Sinergi. Generasi Pesona Indonesia (GenPI) Jateng, Dinas Pariwisata, Pemuda dan Olah Raga Kabupaten Klaten. (10).Monitoring dan Evaluasi Berdasarkan Indikator Keberhasilan Program. Tim Pengabdian Kepada Masyarakat melakukan monitoring dan evaluasi secara periodik pada program, sehingga masalah dapat diatasi dan program-program berjalan berkelanjutan. Monitoring dan evaluasi didasarkan pada parameter indikator keberhasilan program. (11).Lokakarya Hasil dengan Menghadirkan Stakeholder Program. Lokakarya menghadirkan stakeholder (BUMDes Sinergi, perangkat desa, kecamatan, Dinas Pariwisata, Pemuda dan Olah Raga Kabupaten Klaten) bertujuan mengevaluasi dan merencanakan program supaya berkelanjutan. (12).Pelaporan Laporan dibuat di akhir program sebagai pertanggungjawaban atas kegiatan yang telah dilaksanakan. (13).Pemutakhiran Data Sasaran Pascaprogram per 2 Bulan (Pemantauan keberlanjutan program dilakukan pemutakhiran data sasaran per 2 bulan yang meliputi: keberadaan aset atau bangunan fisik dan pelaksanaan program).

Pada tahap akhir, dampak positif berwujud perubahan perilaku masyarakat dan meningkatnya pengetahuan serta keterampilan dalam pengelolaan sumber daya lokal menjadi komoditas unggulan desa diukur secara kualitatif. Hasil pengukuran indikator awal dilakukan dengan pretest dan posttest pada saat sebelum dan sesudah sosialisasi. Peningkatan pengetahuan dan sikap diukur dengan membandingkan nilai pretest (capaian rata-rata 55\%) dan posttest (capaian nilai rata-rata 75\%) dengan uji Wilcoxon. Hasil pretest dan posttest yang dianalisis secara deskriptif dalam bentuk tabulasi menunjukkan hasil yang relatif efektif karena mempunyai nilai $\geq 64 \%$. Berkait perubahan tingkat pengetahuan dan sikap. Dampak positif bagi mitra Sementara dengan dihasilkannya produk olahan ikan dan sayuran dalam wujud fish skin, bakso ikan, dan nugget ikan, serta produk digitasl seperti katalog virtual berbasis WA Bisnis, secara observasif menunjukkan keterampilan atas program pengabdian yang dilaksanakan.

Meskipun upaya maksimal sudah diaplikasikan dalam pelaksanaan program, namun kondisi pandemi menjadi permasalahan yang tidak sederhana untuk diselesaikan. Oleh karenanya, setelah kegiatan ini berlangsung dengan tuntas, masih terdapat harapan keberlanjutan program. Pada saat yang sama, harapan bahwa pemasaran produk dapat menjangkau wilayah yang lebih luas pasca peletakan forndasai virtual dilakukan, tidak hanya menjangkau kawasan di Kabupaten Klaten tapi juga di luar daerah, meski saat ini kondisi pandemi belum menunjukkan tanda-tanda mereda.

\section{KESIMPULAN}

Langkah utama pelaksanaan pengabdian yang dibagi dalam empat tahap dengan bermitra dengan Pokdarwis BUMDes Sidowayah menghasilkan fondasi virtual dalam pengembangan komodifikasi lokal menghadapi era Revolusi Industri 4.0. Tahap pertama menggunakan metode instruksional dan komunikasi dua arah melalui kegiatan sosialisasi urgensi penguatan branding produk lokal yang sudah dikembangkan dalam komoditas nugget, bakso dan fish skin. Tahap kedua praktik pengemasan produk dan penguatan konten branding dan pendaftaran merek dagang berbasis perlindungan Hak Kekayaan Intelektual (HKI). Tahap ketiga, pemasaran digital yang memanfaatkan sosial media serta publikasi lini massa dan online. Tahap keempat, monev atas kegiatan penguatan branding dan proteksi HKI produk Sidowayah.

Rekomendasi yang dapat disampaikan sebagai tindak lanjut program yaitu, meski pelaksanaan pengabdian belum optimal akibat pandemi Covid-19, program pengabdian setidaknya

$$
\text { Ekonomi, Sosial, dan Budaya }
$$


telah berimplikasi pada peletakkan fondasi virtual yang kukuh untuk terciptanya penguatan branding produk unggulan desa yang dikomodifikasi untuk meningkatkan income generating. Modalitas sosial demikian patut dilanjutkan dengan beragam inovasi guna terwujudnya masyarakat yang berdikari dalam ekonomi kerakyatan berbasis produk lokal.

\section{UCAPAN TERIMA KASIH}

Ucapan terima kasih Tim Pengabdi sampaikan kepada Universitas Sebelas Maret yang telah mengalokasikan pendanaan PNBP UNS, dan selanjutnya dilaksanakan oleh LPPM di tahun 2020 ini yang telah menyelenggarakan kompetisi Hibah Reseacrh Group dan menyelenggarakan monev dengan sangat baik.

\section{REFERENSI}

\section{Britha, Mikkelsen. (2011). Metode Penelitian Partisipatoris dan Upaya} Pemberdayaan. Yayasan Pustaka Obor Indonesia, Jakarta.

Chambers, R. (1996). P.R.A.Participatory Rural Appraisal, Memahami Desa Secara Partisipatif. Kanisius, Oxfam dan Yayasan Mitra Tani, Yogyakarta.

Direktorat Jenderal Cipta Karya. (2012). Agropolitan dan Minapolitan. Konsep Kawasan Menuju Keharmonian.

Ginting, E. (1991). Metode Kuliah Kerja Lapang. Universitas Brawijaya, Malang.

Hasmawati, F. (2018). Ekonomi
Kerakyatan Berbasis Potensi Lokal. Yonetim: Jurnal Manajemen Dakwah, 1(1), pp. 62-76.

Morissan, M.A., 2012. Metode Penelitian Survei. Kencana Prenada Media Group, Jakarta.

Ningrum, M.N., H. Santoso dan A. Syauqi. (2019). Analisa Kadar Protein Ikan Nila (Oreochromis Niloticus) yang Diawetkan dengan Biji Picung Muda (Pangium edule Reinw). e-Jurnal Ilmiah SAINS ALAMI (Known Nature) Volume 2/ No.: 1/ halaman $37-43$.

Indreswari, R. Rustamaji, M. Ibad, I. (2019). "Pengembangan Pariwisata Kreatif Berbasis Komunitas dan Budaya Lokal Sebagai Usaha Pemberdayaan Masyarakat di Desa Pojok, Tawangsari, Sukoharjo", Senadimas, Unisri, Surakarta.

Sabil. (2014). Sistem Ekonomi Kerakyatan Sebagai Landasan Pembangunan Ekonomi Indonesia Melalui UKM, Koperasi dan Pemerintah Daerah Moneter, Vol. I No. 1 April 2014:51

Suyanto, S. R. (2010). Pembenihan dan Pembesaran Nila. Penebar Swadaya. Jakarta.

Widjaja, Haw. (2008). Otonomi Desa Merupakan Otonomi Asli Bulat dan Utuh. Jakarta: PT Raja Grafindo.

$\begin{array}{crrr} & \text { Yuswohady. } & \text { (2015). "Panca } & \text { Sila Juara } \\ \text { MEA", } & \text { Koran } & \text { Sindo, } & \text { Jakarta. }\end{array}$

